\title{
Editorial: People - Marine Mammal Interactions
}

\author{
Andy Butterworth * and Mark P. Simmonds \\ Clinical Veterinary Science, University of Bristol, Bristol, United Kingdom \\ Keywords: marine mammal, humans, interactions, welfare, policy making
}

\section{Editorial on the Research Topic}

\section{People - Marine Mammal Interactions}

Our relationships with marine mammals are complex. We have used them as resources, and in some places this remains the case; viewed them as competitors and culled them (again ongoing in some localities); been so captivated and intrigued that we have taken them into captivity for our entertainment; and developed a lucrative eco-tourism activity focused on them in many nations (Brakes and Simmonds, 2011). In fact, the history and even the economic success of many maritime nations has been intimately intertwined with exploitation of marine mammals. In the United Kingdom, for example, stranded cetaceans were once used opportunistically for food, and this later developed into organized hunting, with the value of cetaceans recognized in 1,324 when a statute was enacted giving the English sovereign qualified rights to stranded and captured animals (Simmonds, 2011). The Scottish crown quickly moved to claim the same rights. Later, British interests moved from a focus on whale meat to whale oil and land stations and far-seas whaling followed. Ultimately, it was whale oil that helped to light the streets and factories of the industrial revolution and lubricate its machines. Britain was, of course, far from being alone in mining the whales for their oil and, come the twentieth century, as whale stocks dwindled, the UK was one of the founding member nations of the International Whaling Commission (IWC).

When we first envisaged this special topic, we had two overarching aims. Firstly, we hoped to generate critical evaluation of some of our relationships with these animals and, secondly, we hoped to attract knowledgeable commentators and experts who might not traditionally publish in the peer-reviewed literature. We were also asking ourselves a question about what responsibility humankind might have to marine mammals, on our rapidly changing planet. Readers will judge our success for themselves, from the papers in this special issue, which cover;

*Correspondence: Andy Butterworth andy.butterworth@bris.ac.uk

Specialty section:

This article was submitted to Marine Affairs and Policy, a section of the journal Frontiers in Marine Science

Received: 15 March 2017 Accepted: 26 May 2017 Published: 08 June 2017

Citation:

- "Aquatic bushmeat"-consumption in developing parts of the world;

- Bycatch-Gulf of Guinea;

- The recent evolution of the IWC;

- Welfare concerns relating to seal shooting-Scotland;

- Dolphin harassment-Gulf of Mexico;

- The welfare implications of marine debris for pinnipeds;

- "Small Type Coastal Whaling" and whaling policy-Japan; and

- The conservation implications of cetacean culture.

These are diverse, and challenging topics, although there are, of course, others that could have been addressed. Notable omissions might include consideration of marine noise pollution (e.g., Simmonds et al., 2014); chemical pollution (as recently highlighted by Jepson and Law, 2016) and more discussion of the various ongoing hunts of cetaceans and seals (e.g., Butterworth and Richardson, 2013; Butterworth et al., 2013; Butterworth, 2014; Simmonds and Corkeron, 2016) which currently take place in coastal and international waters. 
Powered by oil and gas, electricity, plastics and steel, the aeroplane, the car, and the gun, human influence, and creeping tentacles of human population growth can now be felt across the entire surface of the planet. The United Nations (United Nations, 2015) estimate that the global human population will reach $10.1 \mathrm{bn}$ in 2100 . Increasingly, the world's people live in cities; Osaka, Karachi, Jakarta, Mumbai, Shanghai, Manila, Seoul, Beijing, Mexico City, São Paulo, New York, Lagos, Los Angeles, and Cairo each now have close to or more than 20 million people. Delhi and Tokyo are forecast to reach 40 million people within the next decade. Humans and their cities need food and fuel, and spread across coastal land. Human wastes are driving climate change, ocean pollution (including marine debris), and air pollution. Even if population growth slows, humankind and its mark on the planet and its animals is already deeply scored into the surface of the earth, and will be for a long, geologically long, time.

The science of marine mammal-human interaction and marine mammal welfare is starting to enter the political arena at a high level. At its 65th meeting, in 2014, the IWC agreed to direct a programme of work to address human activities which can adversely affect cetacean welfare; including the welfare concerns that arise when large whales become entangled in fishing gear and to work on the methods used to euthanize stranded whales and the effectiveness of those methods. We attended the first IWC workshop (May 2016), which had a sole focus of considering nonwhaling welfare issues (IWC, 2017). There is clearly a growing interest in marine mammals and human interactions.

Historically there has been an understandable focus on the effects of negative human marine mammal interactions.

\section{REFERENCES}

Brakes, P., and Simmonds, M. P. (eds.). (2011). Whales and Dolphins Cognition, Culture, Conservation and Human Perceptions. London: Earthscan Ltd.

Butterworth, A. (2014). The moral problem with commercial seal hunting. Nature 509:9. doi: 10.1038/509009a

Butterworth, A., Brakes, P., Vail, C. S., and Reiss, D. (2013). A veterinary and behavioral analysis of dolphin killing methods currently used in the “drive hunt" in Taiji, Japan. J. Appl. Anim. Welfare Sci. 16, 184-204. doi: 10.1080/10888705.2013.768925

Butterworth, A., and Richardson, M. (2013). A review of animal welfare implications of the Canadian commercial seal hunt. Mar. Policy 38, 457-469. doi: 10.1016/j.marpol.2012.07.006

IWC (2017). Report of the Workshop to Support the IWC's Consideration of NonHunting Related Aspects of Cetacean Welfare. IWC/66/WKM\&WI Rep 01. 34 pages. Available online at: https://archive.iwc.int/pages/view.php?ref=6230\&k= c0e34c50b4

Jepson, P. D., and Law, R. J. (2016). Persistent pollutants, persistent threats: polychlorinated biphenyls remain a major threat to marine apex predators. Science 352, 1388-1389. doi: 10.1126/science.aaf 9075
However, positive experiences and states are now recognized to be (at least) as important as negative states in their contribution to overall animal well-being. Marine mammal science is starting to include elements of not just the physical aspects of the animals life (injury, environmental change, pollution, noise) but also the mental state of the animal, whether the animal can express a range of "normal" behaviors, and whether the animal can fulfill its essential nature or "telos."

The answer to the question; can, or should, humans have responsibility for the lives of marine mammals when they are affected by the activity of mankind? - is, in our opinion, "yes"and the logical progression from this question is to direct research and effort to understand and optimize the actions, reactions, and responses that mankind may be able to take. We hope that the papers in this special issue bring some illumination to a small selection of topics under this much wider topic area, and prove to be informative and stimulating.

\section{AUTHOR CONTRIBUTIONS}

All authors listed, have made substantial, direct and intellectual contribution to the work, and approved it for publication.

\section{ACKNOWLEDGMENTS}

We would like to thank the Humane Society International for sponsoring this special topic by covering the publishing fees. We also thank all of the referees for their very valuable contributions and the staff at Frontiers for their help.

Simmonds, M. P. (2011). "The British and the whales," in Whales and Dolphins Cognition, Culture, Conservation and Human Perceptions, eds P. Brakes and M. P. Simmonds (London: Earthscan Ltd.), 56-75.

Simmonds, M. P., and Corkeron, P. (2016). A deal on whaling is a bad idea. A response to Gerber. Front. Ecol. Environ. 14:1263. doi: 10.1002/fee.1263

Simmonds, M. P., Dolman, S. J., Jasny, M., and Leaper, R. (2014). Marine noise pollution - increasing recognition but need for more practical action. J. Ocean Technol. 9, 71-90.

United Nations (2015). UN Department of Economic and Social Affairs, Population Division. World Population Prospects: The 2015 Revision, Vol. 1, Comprehensive Tables. ST/ESA/SER.A/379.

Conflict of Interest Statement: The authors declare that the research was conducted in the absence of any commercial or financial relationships that could be construed as a potential conflict of interest.

Copyright (c) 2017 Butterworth and Simmonds. This is an open-access article distributed under the terms of the Creative Commons Attribution License (CC BY). The use, distribution or reproduction in other forums is permitted, provided the original author(s) or licensor are credited and that the original publication in this journal is cited, in accordance with accepted academic practice. No use, distribution or reproduction is permitted which does not comply with these terms. 